
MECHANICAL AND VISCOELASTIC PROPERTIES OF YAM

(Dioscorea alata)

Authors: ARMANDO ALVIS ${ }^{1}$, MAR VILLAMIEL ${ }^{2 *}$ and MAITE RADAMENDOZA $^{3}$

6

71 University of Córdoba, Cra 6 No. 76-103, Km. 3, vía Cereté. Córdoba, Colombia

82 Instituto de Fermentaciones Industriales (CSIC), c/ Juan de la Cierva, 3. 28006.

$9 \quad$ Madrid, Spain

103 Professor University of Cauca, Chemistry Department, Investigation Group

11 BICAMSA, c/ 5 No. 4-70. Popayán, Colombia

12

13 *Author to whom correspondence should be addressed

14 Telephone number: (34) 915622900 Ext. 397

15 Fax number: (34) 915644853

16 e-mail: $\underline{\text { mvillamiel@ifi.csic.es }}$ 
ABSTRACT

2

3 The main mechanical properties and viscoelastic characteristics of two different

4 cultivars of yam has been measured in this work. Using an Instron machine, some

5 different tests has been applied: puncture, uniaxial compression and bending in order to

6 calculate the parameters: maximum stress of penetration, stress and strain at fracture,

7 deformability modulus and the constants " $a$ " and " $b$ " from the Peleg model. It is

8 concluded that the Pico de Botella cultivar has a fracture stress higher (0.57 MPa) than

9 the Diamante 22 cultivar $(0.31 \mathrm{MPa})$ and also the degree of deformation at fracture is

10 higher (32\% versus $21 \%$ ). In relation with the constants from the Peleg viscoelasticity

11 model, there are no differences between cultivars, both having the same value of the

12 asintotic stress $(a=0.43)$ and very similar for the relaxation stress rates (Pico de

13 Botella, $b=0.03$ and Diamante 22, $b=0.02$ ).

14

\section{KEYWORDS}

16 Yam, mechanical properties, viscoelasticity. 
Among the main agricultural products of the Atlantic Coast of Colombia, yam is

3 the most inexpensive and profitable product which is cultivated with corn, cassava or alone. Yam contains better nutritional value (proteins, essential amino acids and minerals) than other roots and tubers such as cassava and potato (Coursey and Ayensu 1972), and literature concerning production and processing is not commonly available (Morales 1992). World-wide production of yam has grown $4.7 \%$ annually for the last twenty six years from 1.34 million to 4.42 million Ha. The four major producers of yam are Nigeria, Ghana, Benin and Togo. Colombia is the fifth

The high moisture content of yam could be the cause of vulnerability to mechanical damages during processing, handling and storage. Nwandikom (1990) has carried out an extensive work with some cultivars of yam in Nigeria, by using different mechanical techniques: impact load resistance, tissue fracture and compression of tuber tissue. This author concluded that mechanical damage to yam tubers is the major limiting factor of the automatization of its production and increased productivity. Also that mechanical properties (penetration, flexibility, viscoelasticity and uniaxial compression) play a major role in predicting physical damage to tubers and that tubers with more than $70 \%$ moisture content must be placed singly. On the other hand, Aluko and Koya (2006), have pointed out that adequate knowledge of their engineering properties is an essential prerequisite for the scientific design and development of equipment for planting and handling yams setts mechanically. 
$1 \quad$ Calzada and Peleg (1978), have interpreted the relationship stress/deformation

2 during the compression of solid foods (potato) and they explained that two

3 antagonistic mechanisms which regulate the levels of stress exist: the internal

4 fractures, that diminish the mechanical strength and the compactation that has the

5 tendency to increase it. A simple model that only contains two constants (a and b)

6 has been of great applicability to compare the form of the relaxation curves for

7 different materials such as potatoes, apple, pear, etc., (Peleg 1979).

8

9 Currently, there are not data in the literature of this type of measures in yam; for 10 this reason, in the present work a study to characterize the main mechanical 11 properties of two varieties of fresh yam cultivated in the Atlantic Region of 12 Colombia has been carried out.

\section{MATERIALS AND METHODS}

Samples

Two varieties of yam (Dioscorea alata): Diamante 22 and Pico de Botella were selected presenting the best characteristics in reduced sugar content to be used in the deep fat frying process (Alvis and Vélez 2006). These samples were acquired in the

19 germoplasm bank of the University of Cordoba (Colombia) and were stored during $20 \quad 90$ days to $28^{\circ} \mathrm{C}$ until its posterior analysis.

\section{Mechanical determinations}

The "maximum penetration stress" $\left(\sigma_{\max }\right)$ of the whole tuber with peel on, and of

$243 \mathrm{~cm}$ thick slices was measured with two Magness-Taylor probes $(7.9$ and $4.6 \mathrm{~mm}$

25 diameter) mounted in an Instron machine. 
The "fracture stress" $(\sigma)$ was measured by a three-point bending test according to Bruns and Bourne (1975). The sample was cut into bars $0.8 \times 0.8 \times 40 \mathrm{~mm}$ long. The bars were placed on a bridge with the supports $20 \mathrm{~mm}$ apart and a descending bar in the center descended until the bar fractured. The fracture stress " $\sigma$ " for a symmetrical beam of rectangular cross-section is:

$$
\sigma=\frac{3 F L}{2 b h^{2}}
$$

Where $b$ and $h$ are the dimension of the cross-section and $L$ the length. and the deformability modulus, and stress and strain at fracture calculated.

In all the previous cases, the tests were made at a deformation speed of 5 $13 \mathrm{~cm} / \mathrm{min}$, at room temperature $\left(25^{\circ} \mathrm{C}\right)$ and taking 5 replicates (different batches of 14 yam) of each experiment.

The relaxation test was performed by compressing $20 \mathrm{~mm}$ cubes of yam by $20 \%$ and holding that degree of compression for 8 minutes while measuring the decay in 18 force (see figure 1).

The viscoelastic properties of solid foods frequently have been demonstrated by 21 relaxation curves (Peleg 1979). An ideal mathematical representation of a physical 22 phenomenon is based on the following:

a. The constants and the equations components, carry meaningful physical information; and 
1 b. The equation is sensitive to physical changes in the system but insensitive to arbitrary parameters.

To apply these conditions to relaxation curves a convenient mathematical

$4 \quad$ procedure has been tested.

a) The relaxation curves have been normalized, i.e. the decaying parameter $Y(t)$ was calculated as follows:

$$
Y_{(t)}=\frac{F_{0}-F_{t}}{F_{0}}
$$

8 Where $F_{t}$ is the force recorded after $1 \mathrm{~min}$ at relaxation.

9 b) The typical shape of the function $Y_{t}$ versus $\mathrm{t}$ suggests the simplified 10 mathematical form of Mickley et al. (1957):

$$
Y_{(t)}=\frac{a b t}{1+b t}
$$

12 Where $\mathrm{a}$ and $\mathrm{b}$ are constants.

If $\mathrm{a}=0$ the stress does not relax at all (i.e. in an ideal elastic solid) and if $\mathrm{a}=1.0$

14 the stress level eventually reaches zero (e.g. in liquids). For $0<a<1$, a represents the 15 asymptotic residual values of $Y_{(\infty)}$. The constant b is the representative of the "rate" 16 at which the stress relaxes ( $1 / \mathrm{b}$ is the time necessary to reach the level of $a / 2)$.

18 One of the mathematical characteristics of equation (4) is that it gives a straight 19 line when plotted in the form:

$$
\frac{t}{Y_{(t)}}=\frac{1}{a b}+\frac{t}{a}
$$


Statistical

2

3

4

\section{RESULTS AND DISCUSSION}

1. Puncture test. Sliced samples showed a decrease in the $\sigma_{\max }$ values in comparison with those of whole tuber samples. With the probe of $7.9 \mathrm{~mm}$, the $\sigma_{\max }$ values were lower for both cultivars (Table 1).

As it is shown from the results of the t-student test, the values of $\sigma_{\max }$ for the whole yam with peel, are not significantly differences $(\mathrm{p} \leq 0.05)$ when using both probe, however when the puncture test is carried out on the tissues, the value of $\sigma_{\max }$ is different among varieties, being higher for Pico de Botella, due to that its peel is harder and has less sugar content (0.16) in comparison to Diamante $22(0.46)$. These differences could be due to the structure and to the composition of the product or both (Mohsenin 1965).

2. Flexure. The Diamante cultivar has a lower fracture force $(9.9 \mathrm{~N})$ and lower deformability $(5.5 \mathrm{~mm})$ than the Pico de Botella cultivar $(16.0 \mathrm{~N}$ and $6.1 \mathrm{~mm})$. See Table 2. This indicates that the Pico de Botella cultivar fractures to much more stress than Diamante 22 and the latter is also something more flexible because it reaches higher values of deformation up to the fracture moment. 


\section{Uniaxial compression}

These results (Table 2) confirm that the cultivar Pico de Botella is much more resistant to the applied forces to deform the product and therefore, less susceptible to mechanical damages occurring during the crop, manipulation, storage and processing, in agreement with the results reported by Nwandikom (1990). For the variety Pico de Botella, the fracture takes place at higher values of the stress and it allows that the same one can be compressed to higher deformations, while the variety Diamante 22 fractures at degree of compression around 20\%. Diehl and Hamann (1979), for fresh potatoes, have reported results close to $30 \%$.

\section{Relaxation}

Figure 1 shows the experimental curves obtained when the function force $(t / Y)$ (s) versus time $(\mathrm{t})$ is plotted.

The fixed normalized and linealized Peleg equation offers the following results:

$$
\begin{array}{lll}
\text { Diamante 22: } & t / Y=2.34 t+110.68 & \mathrm{R}^{2}=0.996 \\
\text { Pico de Botella: } & t / Y=2.308 t+65.78 & \mathrm{R}^{2}=0.998
\end{array}
$$

The coefficient of determination is highly significant $(\mathrm{p}>0.001)$ for both cases. Right similar (Peleg 1979) has also obtained for fruits such as apple and pear as well as some tubers like potato.

The Peleg "a" and "b" constants show hardly any differences between the two cultivars (See table 2).

In agreement with the interpretation of these constants and the value of $\mathrm{a}=0.6$ reported by Peleg (1979) for potato, it can be said that both yam cultivars are closer 
1 to a Hookean solid than potato, that which belongs together with the relative little

2 moisture that presents the yam (70\%) and their high content of starch (28\%) with

3 regard to the potato. Potato is very moisture (75.5\%), therefore, viscoelastic, less

4 solid and less starches (22\%) that are degraded into sugar.

It seems to be that definitively the mechanical properties of yam and their

6 texture, are mainly governed by the composition of the product which it is in

$7 \quad$ agreement with the conclusions pointed out by (Onayemi et al. 1987; Afoakwa and

$8 \quad$ Sefa-Dedeh 2001).

\section{CONCLUSIONS}

11 The flexion test results are higher for Pico de Botella. Pico de Botella variety is

12 less susceptible of being damaged by effect of manipulation during harvest and

13 storage because it is much more resistant to the applied forces to deform the product

14 and viscoelastic properties of both varieties are next to zero. For this reason, the

15 product tends to behave close to the Hooke solid.

\section{Acknowledgements}

This work has been funded by Ministry of Education and Science of Spain 


\section{REFERENCES}

AFOAKWA, E.O. and SEFA-DEDEH, S. 2001. Chemical composition and quality changes occurring in Dioscorea dumetorum pax tubers after harvest. Food Chem. 75, 85-91.

ALUKO, O.B. and KOYA, O.A. 2006. Some engineering properties of yam setts from two species of yams. J. Food Eng. 76, 396-401.

ALVIS, A. and VÉLEZ, C. 2006. Determinación del coeficiente de transferencia de calor del ñame (Dioscorea alata) durante un tratamiento térmico por inmersión.

Doctoral Proposal, Food Engineering Department, Universidad del Valle, Cali, Colombia.

(1)
snapping force of crisp foods. J. Texture Studies 6, 445-448.

BRUNS, A.J. and BOURNE M.C. 1975. Effects of sample dimensions on the CALZADA, J.F. and PELEG, M. 1978. Mechanical interpretation of compressive stress-strain relationships of solid foods. J. Food Sci. 43, 1087-1092. CORPORACIÓN PBA. 2004. Estrategias de comercialización de plátano, yuca y ñame, Bogotá, Colombia.

COURSEY, D.G. and AYENSU, J. 1972. Post harvest problems of yam (Dioscorea spp). In $1^{\text {st }}$. International symposium on tropical roots crops. St Augustine, Trinidad.

DIEHL, K.C. and HAMANN. D.D. 1979. Relationships between sensory profile parameters and fundamental mechanical parameters for raw. Potatoes, melons and apples. J. Texture Studies 10, 401-420.

MICKLEY, H., SHERWOOD, T.K. and REED, C.E. 1957. Applied Mathematics in Chemical Engineering, Mc Graw-Hill Book Co, New York. 
MOHSENIN, N.N. 1965. Physical Properties of Agricultural Products.

2 Transactions of the American Society of Agricultural Engineers 8, 25-29. MORALES, T.L. 1992. El Cultivo del Name y su Potencialidad en el Caribe Colombiano. C. I. ICA, Carmen de Bolívar, Cartagena, Colombia.

NWANDIKOM, G.I. 1990. Yam tuber resistance to mechanical damage. Agricultural Mechanization in Asia, Africa and Latin America 21, 33 -36.

ONAYEMI, O., BABALOLA, R.O. and BADANGA, A. 1987. Textural properties of cooked tropical yam (Dioscorea spp). J. Texture Studies 18, 17-29.

PELEG, M. 1979. Characterization of the stress relaxation curves of solid foods. J. Food Sci. 44, 277-281. 
$1 \quad$ Figure captions

2 FIGURE 1.

3 EXPERIMENTAL CURVES FORCE (t/Y) VERSUS TIME ( $\mathrm{t})$ ACCORDING TO

4 PELEG MODEL FOR BOTH CULTIVAR

5

6

7

8

9

10

11

12

13

14

15

16

17

18

19

20

21

22

23

24

25 
1 TABLE 1.

2 RESULTS OF THE MAXIMUM PUNCTURE STRESS $\left(\sigma_{\max }\right)$ EXPRESSED IN MPa.

3 DATA ARE MEAN VALUES $( \pm$ STANDARD DEVIATION $)$ OF 5

4 DETERMINATIONS.

5

\begin{tabular}{lcccc}
\hline & \multicolumn{3}{c}{ Whole tuber } \\
\cline { 2 - 5 } Cultivar & \multicolumn{4}{c}{ Plice } \\
\cline { 2 - 5 } & 4.6 & 7.9 & 4.6 & 7.9 \\
\cline { 2 - 5 } & $3.72^{\mathrm{a}} \pm 0.68$ & $2.18^{\mathrm{a}} \pm 0.17$ & $1.27^{\mathrm{a}} \pm 0.09$ & $1.11^{\mathrm{a}} \pm 0.04$ \\
\hline Diamante 22 & $3.30^{\mathrm{a}} \pm 0.30$ & $2.20^{\mathrm{a}} \pm 0.42$ & $1.66^{\mathrm{b}} \pm 0.16$ & $1.26^{\mathrm{b}} \pm 0.16$
\end{tabular}

6 Confidence level at $\mathrm{p} \leq 0.05$; Means followed by different letters in each column were significantly

7 different $\mathrm{p} \leq 0.05)$

8

9

10

11

12

13

14

15

16

17

18

19

20 
1 TABLE 2.

2 MECHANICAL PROPERTIES (FLEXURE, UNIAXIAL COMPRESSION AND

3 RELAXATION) FOR BOTH YAM CULTIVARS. DATA ARE MEAN VALUES ( \pm

4 STANDARD DEVIATION) OF 5 DETERMINATIONS.

5

\begin{tabular}{ccc}
\hline \multirow{2}{*}{ Mechanical Property } & \multicolumn{2}{c}{ Cultivar } \\
\cline { 2 - 3 } & Diamante 22 & Pico de Botella \\
\hline FLEXURE
\end{tabular}

Fracture force $(\mathrm{N})$

$9.9 \pm 0.7$

$16.0 \pm 1.2$

Deformability (mm)

$5.5 \pm 0.3$

$6.1 \pm 0.3$

\title{
UNIAXIAL COMPRESSION
}

Fracture stress (MPa)

$0.31 \pm 0.02$

$0.57 \pm 0.04$

Fracture strain (mm)

$0.21 \pm 0.02$

$0.32 \pm 0.02$

Deformability modulus (MPa)

$1.48 \pm 0.13$

$1.78 \pm 0.14$

\section{RELAXATION}

Peleg "a"

$0.43 \pm 0.1$

$0.43 \pm 0.1$

Peleg "b"

$0.02 \pm 0.0$

$0.03 \pm 0.0$

\begin{abstract}
6
\end{abstract}
7

8

9

10

11

12

13 


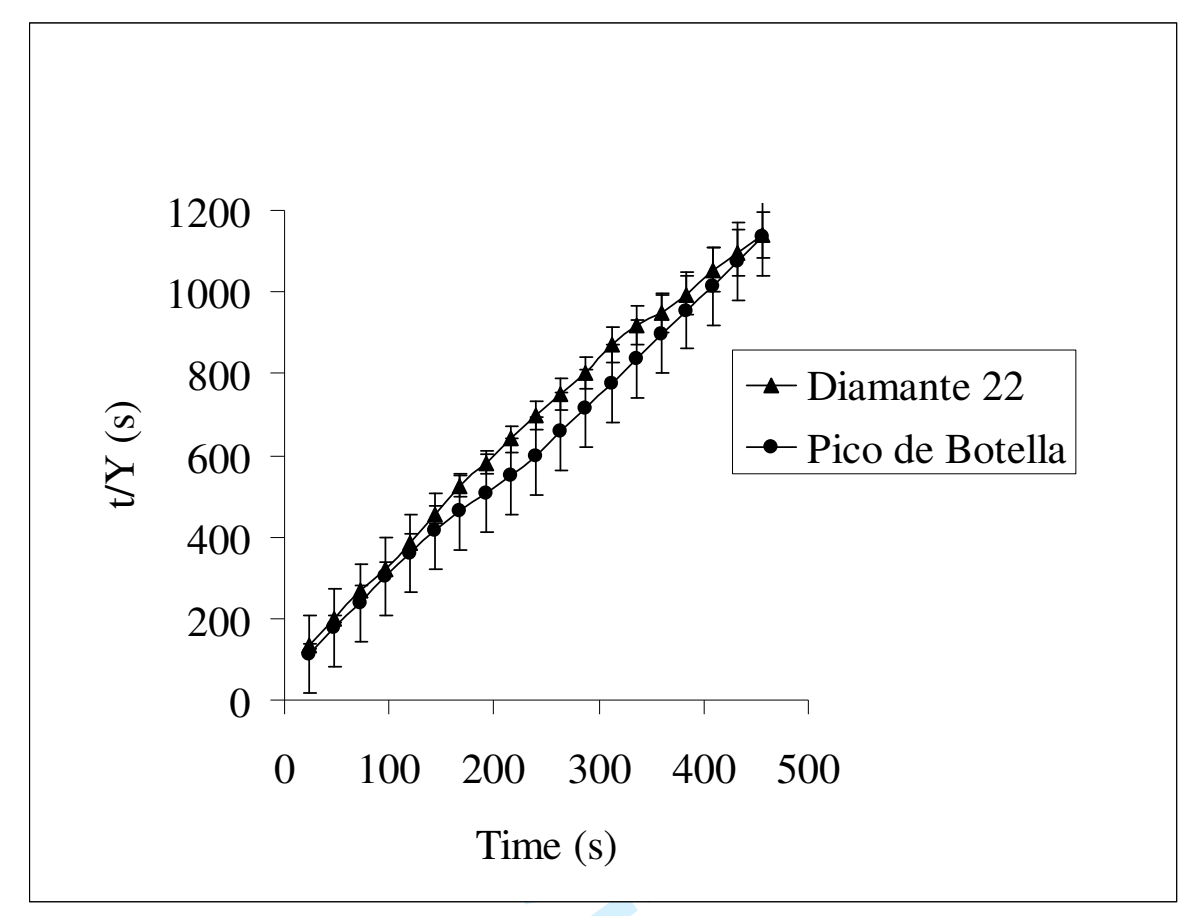

Time (s)

5

6

7

8

9 